\title{
Comparative analysis of problem-solving ability among JSS mathematics students using computer-assisted instruction blended with problem- solving approach (CAI-PS) versus traditional teaching approach (TTP) in teaching basic statistics.
}

\author{
${ }^{1}$ Adolphus, Telima and ${ }^{2}$ Aderonmu, Temitope S.B \\ ${ }^{1}$ Department of Science and Technical Education, \\ Rivers state university of science and technology, Nkpolu-oroworukwo, Port harcourt. \\ ${ }^{2}$ Trinitate International School, Igwuruta, Port Harcourt.
}

\begin{abstract}
The focus of this research is to demonstrate and discuss the educational implications of using CAI-PS or TTP in enhancing problem solving abilities among JSS 1 Mathematics students. A survey and quasi-experimental design were employed using the likert scale and the t-test respectively. Research question and two null hypothesis were raised at $5 \%(\alpha=0.05)$ level of significance. Data collecting instruments include the mathematics Teachers questionnaire (MTQ), used for the teachers while the Structural Statistics Test (SST) was used for the mathematics students. Result of the study revealed that unavailability of CAl equipments and low level of teachers' competency in computer usage affects the use of CAI-PS for content delivery .Following the findings of the study, it was recommended amongst others that there should be provision of adequate computers and instructional (teaching) related equipments to facilitate mathematics teaching and learning and compulsory inclusion of computer usage in teaching, for all teacher education programmes.
\end{abstract}

Key words: Problem-solving, computer-assisted instruction, problem-solving approach, traditional teaching approach

\section{INTRODUCTION}

Mathematics teaching attains utmost importance in this contemporary technological world. The level and direction of science, technology and mathematics (STM) depends on both teachers' presentation and knowledge acquisition by students of the concepts, facts and principles embodied in the subject. One major objective of the secondary school education is to prepare students for useful participation in science and technological activities in the society and equipping students with the skills necessary for coping with the demands of higher education (FRN, 2004).

Swarupa (2007) posits that mathematics is an expression of human mind which reflect the active will, contemplative reason and the desire for aesthetic perfection. Its basic element is based on logic and intuition analysis, construction, generality and individuality. Based on this, the mathematics teacher must realise that he is a "talent scout" and consequently focus on the leaner. In line with this,
Abraham and Leigha (2007) agrees that much attention should be given to sustain and improve student efforts based on the cognitive, affective and psychomotor skills, including transferable skills needed for problem solving. The implication is the reduction and consequent elimination of students' "phobia" in respect of mathematics.

Problem solving is regarded as a basic mathematical activity. Since in general, the utmost concern of mathematicians is the success of the student based on the domains of educational objectives and their independent success based on their abilities as problem solvers. Balogun (1982), stressed that problem solving can help students improve their analytic powers and consequently apply these powers in diverse situations including, mathematical facts, skills, concepts and principles by illustrating mathematical applications and the interrelations among objects. As prescribed by Polya (1966), mathematical problem-solving can best be achieved when students are introduced to the problem, able to 
Am. J. Sci. Ind. Res., 2012, 3(2): 81-85

recollect known relationships and fact about the problem, obtain necessary requirements needed for the solution to the problem, analyse the requirements with respect to the relations and verify the solution after analysis.

Sound foundations can be laid when learners' thinking is closely linked with perceptual experiences acquired by seeing, hearing and doing things, the developmental stage of learning at the level of this study as classified by Jean Piaget's theory of cognitive development is between the "late" concrete and "early" formal operational stages.Researchers have shown (Karplus, 1977; Onwu, 1980; Obomanu, 1999) that the use of concrete materials in explaining theoretical concepts enhances problem-solving abilities. It also proposes reflective thinking process after having completed a problem. In this light, effective and enriching classroom teaching and learning considering the types of learning styles of students (visual, auditory, tactile and kinaesthetic) can be accommodated using student- centred instructional presentation. There is no true learning unless the child mentally acts upon information (by seeing, learning, practising), in such process assimilates and accommodates what he encounters.

Mathematics appreciation, understanding and effective feedback process can be achieved when appropriate and simplified presentation is employed. Computer-Assisted Instruction combined with problem-solving approach is an integration of two teaching methods which sends stimuli while presenting to the mental auditory learning and seeing senses of the learner at the same time. In effect, it stimulates and sustains students' interest in mathematics. Several studies have been carried out using CAl in teaching statistics (Oswald, 1996; Harrington, 1999; Spinelli, 2001; Warner and Mechan, 2001). However, literature review shows that only a few studies have particularly examined CAI-PS in teaching foundation statistics for JSS 1 students. Nicholson (1998) and Roiter and Petouz (1996) are of the opinion that CAl in teaching introductory statistics is very important because of the negative feelings and anxiety towards statistics.

The combination of CAI-PS is usually a good beginning in lesson presentation to foundation mathematics students. Afolabi (2011) outlines benefits for the utilization of CAI-PS as development of problem solving skills, development of functional knowledge and manipulative skills, acquisition of scientific appreciation and interest. The primary aim of teaching mathematics is to enable students' development of understanding and skills related to mathematical operations and development of abilities applicable to problem solving. That obviously indicates Packards' (1993) views, that students who are actively involved in their own learning usually become more independent learners and problem solvers.

\section{METHODOLOGY}

The research comprises both survey and quasiexperimental research design. This procedure enables the researchers to achieve both quantitative and qualitative data for the study. Three junior secondary schools located in Ikwerre Local Government Area were used for the study. Forty (40) teachers and a total of 74 JSS 1 students were used for the study. JSS 1 was selected for the study because Introductory Statistics is taught in JSS 1 Mathematics curriculum in Nigeria.

The co-educational school (JSS 1) students were divided into two classes of 21 students each, making two groups. Group A was identified as the CAI - PS group, while group B was the TTP group. Both groups were taught using same number of periods consisting of 40 minutes each for 10 periods spanning a total of two weeks. Group A was taught using CAI-PS approach, while group B was taught using TTP. However, the single educational schools (male and female) were taught using same number of periods as prescribed above and teaching method of CAI-PS. Groups A, B, male and female participants were taught by the same instructor.

Research question and hypothesis: To what extent does CAI - PS approach stimulate efficient teaching and learning?

$\mathrm{Ho}_{1}$ : There is no significance difference in problem solving abilities among JSS1 mathematics students using CAI-PS or TTP in teaching statistics

$\mathrm{Ho}_{2}$ : There is no significance difference in problem solving abilities among male and female JSS1 male and female mathematics students using CAI - PS approach in teaching statistics.

Instrument for data collection: Two types of data collecting instrument were used for the study; Mathematics teachers questionnaires (MTQ) and Structural Statistics Test (SST). The MTQ was employed to obtain response from the teachers as regards the study and utilized specifically for 
research question one. The SST was administered to JSS 1 students used for the study.

The SST consists of 10 essay questions ranging from 1-10. A score of 10 marks was allocated to each question, therefore, a total of 100 marks was used for the SST. The test procedure was employed so as to measure problem-solving effects and originality, indepth knowledge in the area of study. The test content is composed of questions in JSS1 basic statistics including presentation of data, types of data presentation:- Rank order list, frequency table, tally sheet, pictogram, pie chart, line graph and bar chart.

\section{METHOD OF DATA ANALYSIS}

The research question set for the study was analysed using the four point likert scale mean rating method. In decision taking, if the calculated mean (xcal) is above the mean rating $(x=2.50)$, the item statement is "accepted". If the calculated mean (xcal) is below the mean rating $(x=2.50)$ the item statement is "rejected". The parametric-statistics of t-test at $5 \%$ level of significance was used to analyse the null hypothesis.

\section{RESULTS AND DISCUSSION}

The results of the study are presented in the table below.

Research question: To what extent does CAI-PS approach stimulate efficient teaching and learning?

Table 1 revealed that there are not enough CAI equipments which can facilitate CAI-PS in lesson presentation in the schools. This showed a calculated mean (xcal) of 1.38. Also disclosed is the low level of competency in computer usage by the teachers, therefore, inhibiting the method of instructional presentation. Calculated mean(xcal) for item $2=$ 2.20. However, sequential content presentation, effective classroom interaction, classroom time management during content delivery and enhancement of problem solving abilities were shown to be accepted with calculated mean xcal of 2.70 , $2.85,2.80$ and 2.65 respectively.

The response of the teachers as highlighted in the table above revealed that most mathematics teachers used for the study do not have access to computer and its related facilities so as to be able to use the CAI-PS approach. Various research has shown ( Ogunkunle, 2001; Adolphus and Aderonmu, 2011) that the poor state of instructional facilities affects the achievement of students. There should be a shift from the "chalk and talk" approach of teaching to a more realistic, creative, student-centred and students' interest sustainable instructional method. Therefore, emphasizes must be geared towards the teaching of mathematics to balance the dynamic nature of the contemporary technological era. Evidently, the teaching and learning activities cannot be separated from the inevitable application of computers. Balogun (1982), opined that the use of functional and relevant instructional aids develops problem solving skills, manipulative skills and scientific attitudes.

Table 1: Mean rating of teachers response on efficient use of CAI-PS approach

\begin{tabular}{|r|l|l|l|}
\hline S/no & \multicolumn{1}{|c|}{ Item Statement } & Xcal & Decision \\
\hline 1. & $\begin{array}{l}\text { There are available } \\
\text { computer- } \begin{array}{r}\text { assisted } \\
\text { instructional } \\
\text { equipments in the school }\end{array}\end{array}$ & 1.38 & Rejected \\
\hline 2. & $\begin{array}{l}\text { I have high level of } \\
\text { competency in the usage of } \\
\text { CAl equipments }\end{array}$ & 2.20 & Rejected \\
\hline 3. & $\begin{array}{l}\text { CAl-PS ensure sequential } \\
\text { content presentation during } \\
\text { lesson delivery }\end{array}$ & Accepted \\
\hline 4.70 & $\begin{array}{l}\text { CAl-PS ensures effective } \\
\text { interaction between teachers } \\
\text { and students during teaching } \\
\text { and learning }\end{array}$ & Accepted \\
\hline 5.85 & $\begin{array}{l}\text { Adequate time management } \\
\text { is obtainable during content } \\
\text { presentation by using CAl- } \\
\text { PS }\end{array}$ & $\begin{array}{l}\text { Accepted } \\
\text { CAl-PS stimulates problem- } \\
\text { solving abilities among } \\
\text { students }\end{array}$ & Accepted \\
\hline
\end{tabular}

The study also disclosed that most teachers have little or no knowledge of computer applications in teaching. It is important to stress that mathematics teachers should embrace chance, avail themselves the opportunity to acquire computer training so as to be competent in utilizing computer and its related instructional facilities for teaching. However, the respondents agreed that CAI-PS approach enables sequential content presentation especially when applying the power point instructional presentation. This strategy reveals the fact that content presentation can be done from simple to complex. CAI-PS also assists the teaching and learning process to acquire efficient teacher-student interaction. In line with this, Akubue (1991) established that favourable conditions that will facilitate instructions, giving understandable direction and request to follow certain procedure or desist from 
disruptive behaviour could be ensured when there is effective use of an efficient instructional aid and procedure. This will eventually produce insurable feedback from the students since they participate in solving problems presented by the teacher

\section{Testing of Research Hypotheses}

\section{Hypothesis one}

$\mathrm{Ho}_{1}$ : There is no significance difference in problem solving abilities among JSS 1 mathematics students using CAI-PS or TTP in teaching statistics.

Table 2: Analysis of t-test of difference between CAIPS approaches and TTM among the experimental groups.

The t-test at 5\% level of significance (@=0.05) and 40 degrees of freedom for two-tailed test is given as $\mathrm{t}($ table $)=6.33$. Decision: Since the calculated value $\mathrm{t}(\mathrm{cal})=6.33$ is greater than the table value $\mathrm{t}($ table $)=$ 2.02, therefore, we reject the null hypothesis and uphold the alternative hypothesis. This means that, there is a significant difference in problem solving abilities among JSS I mathematics students using the CAI-PS to the TTM.

\section{Hypothesis Two}

$\mathrm{Ho}_{2}$ : There is no significance difference in problem solving abilities among male and female JSS1 male and female mathematics students using CAI - PS approach in teaching statistics

Table 3: Analysis of t-test of difference in problem solving abilities between male and female students using CAI-PS

\begin{tabular}{|c|c|c|c|c|c|}
\hline Group & Mean & $\mathrm{n}$ & df & T(cal) & $\begin{array}{c}\text { T- } \\
\text { (table) }\end{array}$ \\
\hline Male & 61.8 & 16 & & & \\
\hline Female & 51.3 & 16 & 30 & 4.38 & 2.04 \\
\hline
\end{tabular}

The t-test table above utilising $5 \%$ of level of significance $(@=0.05)$ revealed that the tcal = 4.32, while the $t$ (table $)=2.04$. Decision: Since the calculated value (tcal $=4.38$ ) is greater than the table value $t$ (table $)=2.04$, we reject the nul hypothesis and state that, there is significance difference in problem solving abilities between male and female JSS1 mathematics students using CAI-PS approach in teaching statistics.

\section{CONCLUSION AND RECOMMENDATION:}

The teaching profession is a dynamic one. Modern day mathematics teaches should emphasize on problem solving skills in their students, which can be achieved by using a stress free and highly efficient teaching methodology. The application of learning foundation statistics by using CAI-PS will benefit students by empowering them to develop understanding of statistics concepts.

CAI-PS according to Hornby (1995), creates opportunities to use computers in teaching statistics, provides hands-on activities, supports cooperative learning, and provides active and constructive learning experiences. In this vain, foundation secondary school mathematics teachers should accept innovations in the instructional technological world, fostering effective learning by the students and engaging their interest with the content. Petocz and Raid (2001) finally puts it that when interest is associated to learning, the information will be remembered and applied in real life experience. Such interest can be generated using the appropriate instructional strategy.

Based on the observations from the study, the researchers recommend that,

- well equipped and functional mathematics laboratories should be available in all junior secondary schools.

- purchase of adequate computers and instructional related equipment to facilitate mathematics teaching and learning.

- mathematics teachers should avail themselves the opportunity to acquire computer knowledge so as to use the immense benefits in lessons delivery.

- there should be compulsory inclusion of "use of computer in teaching" for all teachers educational programme in the college of education and faculties of education in the universities

- mathematics teachers should encourage problem solving abilities in students using computer simulation games and mathematical puzzles provided by the use of ICT.

- State ministry of education, school owners and principals as a matter of fact, should provide avenues for training and retraining of mathematics teachers on modern teaching 
methodologies as to eliminate the idea of "phobia" in mathematics.

\section{REFERENCE}

Abraham, N and Leigha M. (2007); Developing and Sustaining Students interest in the classroom. Journal of technical and science education. JOTASE (2007) vol. 16. Nos 1 and 2

Afolabi, M. (2011); Seminar presentation on national training and development programme for private schools teachers in Nigeria (Reference manual). National Centre for Educatonal management and administration, Abuja.

Akubue, A.U (1991): Classroom organisation and management. Owerri, Wisdom publishers limited.

Adolphus. T and Aderonmu, T. (2011). An investigation of problems militating the teaching of gravitational force in physics. A study of secondary school physics teachers in Cross Rivers State. Unpublished.

Balogun T.A (1982); Improvisation of science teaching equipment. Journal of science teachers association of Nigeria 2(2), pg 131-137

Federal Republic of Nigeria (2004). National Policy in Education, Lagos. Federal Government Press.

Harrington, D (1999); Teaching Statistics; A comparison of traditional classroom and programme instruction distance learning approaches. Journal of social work education, 35 (3), pg 343- 352
Hornby, P.E (1995); Using a computerised laboratory as a springboard for transforming a traditional lecture course. Paper presented at the $9^{\text {th }}$ annual conference on undergraduate teaching of psychology, March 2224, Elleville, NY, USA

Ogunkunle, R.A (2000), Students perception of difficult Area in mathematics and the use of instructional materials in secondary schools. Journal of research in contemporary education. 1(1) pg 9-22.

Olswald, P.A (1996). Classroom use of the personal computer to teach statistics. Teaching of psychology, 23, pg 124-126

Packard, A., Holmes, G., and Fortune, J. (1993); A comparison of three presentation methods of teaching statistics. ERIC document Reproduction service No. 365696, Chicago.

Petocz, P, and Reid, A (2001); Students' experience of learning in statistics. Questionnaires mathematical, supplementary, pg 37-45.

Pivan, T, Reid A., and Petocz P. (2002); Statistical laboratories using minitab, SPSS and Excel. A practical comparison. Teaching statistics, 24(2), pg 6875.

Polya G. (1966). On teaching Problem-solving in the Role of Axiomatic and Problem-solving in Mathematics. Ed. Washington D C. The Conference Board of Matheamtical Sciences.

Swarupa, R. (2007): Research in Teaching of Mathematics. APH Publishing Corporation. New Delhi. 